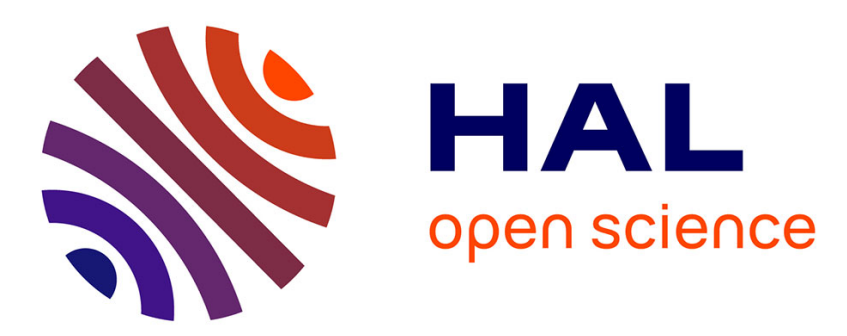

\title{
Plato and the "Internal Dialogue": An Ancient Answer for a New Model of the Self
}

\author{
Alexandru Ovidiu Gacea
}

\section{To cite this version:}

Alexandru Ovidiu Gacea. Plato and the "Internal Dialogue": An Ancient Answer for a New Model of the Self. L. Pitteloud, E. Keeling (dir.). Psychology and Ontology in Plato, 139, Springer International Publishing, 2019, Philosophical Studies Series, 978-3-030-04653-8. 10.1007/978-3-030-04654-5_4 . hal-01975795

\section{HAL Id: hal-01975795 \\ https://hal.science/hal-01975795}

Submitted on 9 Jan 2019

HAL is a multi-disciplinary open access archive for the deposit and dissemination of scientific research documents, whether they are published or not. The documents may come from teaching and research institutions in France or abroad, or from public or private research centers.
L'archive ouverte pluridisciplinaire HAL, est destinée au dépôt et à la diffusion de documents scientifiques de niveau recherche, publiés ou non, émanant des établissements d'enseignement et de recherche français ou étrangers, des laboratoires publics ou privés. 


\section{Metadata of the chapter that will be visualized online}

\begin{tabular}{|c|c|}
\hline Chapter Title & $\begin{array}{l}\text { Plato and the "Internal Dialogue": An Ancient Answer for a New Model } \\
\text { of the Self }\end{array}$ \\
\hline Copyright Year & 2018 \\
\hline Copyright Holder & Springer Nature Switzerland AG \\
\hline \multirow[t]{8}{*}{ Corresponding Author } & Family Name \\
\hline & Particle \\
\hline & Alexandru-Ovidiu \\
\hline & Suffix \\
\hline & Département de Philosophie \\
\hline & Université Grenoble Alpes \\
\hline & Grenoble, France \\
\hline & $\begin{array}{l}\text { alexandru.gacea1@univ-grenoble- } \\
\text { alpes.fr }\end{array}$ \\
\hline Abstract & $\begin{array}{l}\text { The Theaetetus and the Sophist depict one of Plato's most well-known ideas } \\
\text { about thought, namely, the dialogue of the soul with itself. Unfortunately, what } \\
\text { Plato means by this has been obscured by three habits in the scholarship: (1) } \\
\text { to consider the notion as being self-evident, (2) to treat it as being about the } \\
\text { immaterial and universal language of thought, and (3) to understand it through } \\
\text { the distorting lens of the Christian-modern idea of inwardness and inner } \\
\text { private space. I argue for a more tentative reading of "inner dialogue," where } \\
\text { its localization is understood in terms of "physical distinction" and its meaning } \\
\text { is construed around Plato's ideas of polyphony and "microcommunity." } \\
\text { We thereby learn that thinking is a psychophysical process associated with } \\
\text { breathing and that it consists of a "coming-together" of multiple "voices." } \\
\text { "Inner dialogue" is mirrored in the overall structure of Plato's works, and it } \\
\text { represents the very way philosophical debate ought to be conducted. }\end{array}$ \\
\hline $\begin{array}{l}\text { Keywords (separated } \\
\text { by “_" ") }\end{array}$ & $\begin{array}{l}\text { Dialogic mind - Cognitive sciences - Plato - Internal dialogue - Polyphony - } \\
\text { Voice - Microcommunity - Inwardness - Selfhood - Immaterial thought - Inner } \\
\text { private space }\end{array}$ \\
\hline
\end{tabular}




\section{Chapter 4 \\ Plato and the "Internal Dialogue": \\ An Ancient Answer for a New Model \\ of the Self}

\subsection{Introduction}

There has recently been a renewed interest in the dialogical aspect of the human mind. Not only in philosophy (of mind) ${ }^{1}$ but also in neuroscience ${ }^{2}$ and cognitive psychology ${ }^{3}$ is it readily accepted that the mind is "somewhat disunified" and opaque to itself that there is no immediate way to (consciously) access all the resources of the mind (Dennett, 1992). Moreover, we are now able to ascertain the dual or even manifold structure of our brain, and the fact that the activity of the brain consists of millions of different operations occurring per second without us having any awareness of it. It appears that there is, nevertheless, a mediate (and limited) access to the mind's resources. Scholars have started to give serious consideration to the idea that (self-)consciousness or conscious thought usually unfolds as an "internal dialogue." This dialogue would be responsible for assuring the "communication" between different parts of the brain and the "transparency" of some of the processes or operations of the mind.

However, these different fields of knowledge diverge on how we should understand this phenomenon. Although the starting point is always the same, namely, the intuitively familiar phenomenon of an "inner voice," its meaning, role, and purpose and even origin are differently construed in each disciplinary context. For some, ${ }^{4}$ the internal dialogue is actually a monologue, and it represents a mental phenomenon

\footnotetext{
${ }^{1}$ To mention only some representative works: Ryle and Kolenda (1979), Gadamer (1989), Dennett (1991), and Blachowicz (1998).

${ }^{2}$ See Alderson-Day et al. (2015, pp. 110-120).

${ }^{3}$ See Gazzaniga (1985), Fernyhough (1996, pp. 47-62) and Alderson-Day and Fernyhough (2015, pp. 931-65).

${ }^{4}$ I partially base my classification on the one realized by Blachowicz (1999, pp. 177-200).
A.-O. Gacea $(\bowtie)$
Département de Philosophie, Université Grenoble Alpes, Grenoble, France
e-mail: alexandru.gacea1@univ-grenoble-alpes.fr 
accessible to or even constitutive of (self-)reflection, i.e., the capacity of the human mind to think of something internally, to evaluate it and criticize it, and to exercise introspection. For others, ${ }^{5}$ it is the internalization of the social or interpersonal dialogue. ${ }^{6}$ Inner dialogue is not a kind of "subvocal rehearsal," but it represents the nature of "higher mental functions," in other words, functions that are essentially conscious, voluntary, and mediated and originate in social activity and interaction (Fernyhough, 1996). This means that the subject that carries a conversation with itself "takes on the voices of others," that is to say, the others' particular perspectives on reality, their belief and value system or set of attitudes toward reality. Dialogical thinking signifies the ongoing interplay between different perspectives on reality or the "simultaneous accommodation of multiple perspectives upon a topic of thought" (Fernyhough, 2008, pp. 232-233). According to this view, inner dialogue is not necessarily explicit, and it does not even need to appear as dialogue. It is not a mental phenomenon accessible to consciousness, but a capacity constitutive of consciousness. ${ }^{7}$ And there is a third way ${ }^{8}$ of conceiving dialogic thought, where it is less shaped by interpersonal conversation and more a phenomenon inseparably linked to the structure of the brain. In this case, it represents a genuine reciprocal "conversation" between two sides, two distinct "voices": one "more adept at articulation" or conceptual and the other one more intuitive or experiential (Blachowicz, 1999).

But where does this idea of the dialogic mind even come from? Because, to whatever extent it may be derived from the structure of the brain itself, it still has a history and a cultural context of origin, namely, ancient Greece. Even though all of these theories mention Plato's seminal definition of thought as a "dialogue of the soul with itself," Plato or to the transformations that the notion underwent and to the tradition it engendered. I argue that by striving to understand Plato's theory, to contextualize it, and to distinguish it (if possible) from the way the Christian and the modern philosophical tradition appropriated it and construed it, we can better understand some of our essential philosophical problems and difficulties concerning the self and consciousness.

The aim of this paper therefore is to revisit Plato's idea of a "dialogue of the soul" without reading it through the distorting Christian-modern lens, i.e., the tradition of "mental language," "inner word," and "inwardness." I actually claim that our own way of seeing the dialogic mind is less indebted to the former than to the latter.

\footnotetext{
${ }^{5}$ For example: Fernyhough (1996, 2015).

${ }^{6}$ This is what the cognitive sciences call a developmental view of inner speech. According to this approach, inner speech represents the "endpoint of a developmental process involving the gradual internalization of linguistic (and other) semiotic exchanges with others" (cf. Fernyhough \& McCarthy-Jones, 2013).

${ }^{7}$ Cf. Fernyhough (1996, p. 52): “consciousness requires at least the ability to 'see' an element of reality in different ways at the same time." Thus, the key feature of dialogic thought is "the ability simultaneously to adopt multiple orientations to reality."

${ }^{8}$ For example: Blachowicz (1999) and Gazzaniga (1974, 1985).

${ }^{9}$ Theaetetus, 189e-190a and the Sophist, 263e-264b. Translation (with slight modifications) is taken from Plato. Complete Works (1997).
} 
One may consider this the source of our present difficulties in using the model of dialogic thought to objectively explain consciousness, because it always sends us back to a subjective feature of conscious experience. The "inner voice" is something most (if not all) of us experience, but in order to objectively understand this phenomenon, we need to go through the first-person perspective or the subject's privileged access to his own interiority.

Our current research on conscious thought is permeated by specifically modern tension between subjectivist and anti-subjectivist orientations. Even our most "objective" ways of explaining conscious thought and the self cannot elude the metaphysical break between the internal and the external, the subjective and the anti-subjective, and the first-person and the third-person perspective. I claim thus that the "strangeness" of Greek thought, Plato in particular, could play an important role in our current debates, precisely because it does not recognize the aforementioned tension and because it seems to have a different meaning for "interiority" and "inwardness" and even to exclude the idea of privileged access to an "inner world." What we can find instead is a polyphonic and koinonic view of the self. In other words, the dialogue that constitutes the human being is not only "dual" but polyphonic-it is a conversation between multiple (objective) "voices," and it isn't subjective but "communal."It is more like a "thinking-together" than something characteristic to a private inner life. Inner dialogue refers to the nature of the thinking soul, and, thus, it represents a real conversation between different points of view or voices that constitute the soul as an embodied and communal entity.

\subsection{The "Dialogue of the Soul with Itself" in the Theaetetus and the Sophist}

The theme of the dialogic relationship that the $\psi \mathcal{\chi} \chi \dot{\eta}$ entertains with itself appears explicitly in the Theaetetus and the Sophist. ${ }^{10}$ Naturally, one could argue that "dialogicity" represents one of Plato's main concerns throughout the dialogues. ${ }^{11}$ However, I prefer to isolate the way the issue is treated in these two dialogues, because stating explicitly that thought is the "dialogue of the soul with itself" appears to be indicative of a particular Platonic outlook on thought and selfhood. I claim that Plato is subtly moving away from a descriptive perspective, the way thought has always been conceived in Greek culture, toward a prescriptive one, the philosophical appropriation and reinterpretation of this cultural trait. I thus propose not to treat this notion as being self-explanatory.

We should not ignore the fact that the discussion about the soul's silent dialogue occurs in both works in the context of establishing the possibility of falsehood and

\footnotetext{
${ }^{10}$ There is a third passage about the "internal dialogue" in the Philebus (38c-e), but this is more of an example than a description of dialogic thought.

${ }^{11}$ See Gill (1996), Gill and McCabe (1996), Gonzalez (1998), Cossutta and Narcy (2001), Corrigan and Corrigan (2004), Long (2013), etc.
} 
of having false beliefs. If in the Theaetetus, Socrates seems to reject, by appealing to the notion of thought as "silent dialogue," the possibility of false belief in terms

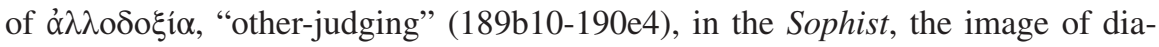
logic thought is introduced after asserting the existence of falsehood and of false discourse. The reasoning is the following: if we can speak falsely (if our speech can "weave" together things that are not linked, e.g., "Theaetetus" and "flying"), then that means we can also think falsely given that thought is a form of $\lambda$ óyos. This doesn't appear to say a lot about the virtues of dialogic thinking since it cannot guarantee truth.

One way to look at it is to say, as some scholars have done, that Plato is looking to criticize, in the Theaetetus, the image of thinking as "mental grasping," which is fashioned on the model of "holding or grasping something in our hands" (Barton, 1999). Plato's solution, in the Sophist, would thus be to see thought as a gradual and partial process: we can only think of a thing "under one or more of its aspects," under one or more concepts, because when we think of a thing we "say" different things about it. Another way to understand the discussion about falsehood and internal dialogue is to say that error or falsehood in thought appears at a conceptual level, that is, when we incorrectly employ the common concepts, when we apply them unreflectively and implicitly to sense experience (e.g., Frede, 1989); or falsehood is due to the linguistic nature of thought, i.e., the compositionality of thought and judgment (e.g., Crivelli, 1998; Duncombe, 2016); or again, error is the result of a botched self-examination, of the incapacity to detect and criticize refutable, false opinions or of the soul's haste to reach a conclusion (e.g., Dixsaut, 2000; Long, 2013; McCabe, 2006).

However, as we will see, the stakes are higher for Plato than simply stating that thought is not "grasping" but "gradually considering different aspects of a thing" or that silent inner dialogue represents discursive or intellectual or, again, dialectic thinking. I argue that these passages indeed refer to the compositionality of thought; by that, however, I mean the multiplicity inherent to thought. The thinking soul does not "speak" in a single authoritative "voice" on the issue it is examining. It is torn between different points of view, some of which are (partially) true and others (partially) false. In other words, "within" oneself false accounts of things are mixed with true ones, ${ }^{12}$ because of the limited and perspectival condition of human thought. ${ }^{13}$

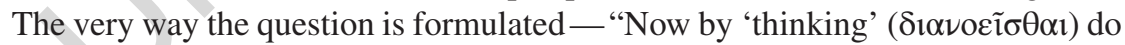
you name the same thing as I do ( $\dot{\gamma} \hat{\omega} \kappa \alpha \lambda \varepsilon \tilde{\imath} \varsigma)$ ?" 14 — seems to indicate a change in denomination. The "name" that Socrates alludes to is not the common word which Greeks (and generally Plato in other dialogues) use to designate "thinking," that is, $\delta ı \alpha \nu$ oี $\tilde{\sigma} \theta \alpha$, but another one, more appropriate for trying to understand what thinking is, namely, $\delta 1 \alpha \lambda \varepsilon \dot{\varepsilon} \varepsilon \sigma \theta \alpha 1$ ("to dialogue" or "to converse"). We know from other dialogues as the Cratylus that how we name things says something about their

\footnotetext{
${ }^{12}$ This is why Plato affirms that truth and error "must be learned together [...] through long and earnest labor," through (incessant) conversation (Letter VII, 344b).

${ }^{13}$ See Kahn (1996, p. 386), Kahn (2005), Gonzalez (2016), and Trabattoni (2016).

${ }^{14}$ Theaetetus, $189 \mathrm{e} 4$ (translation slightly modified).
} 
nature. Names do seem to possess, for Plato, "some sort of natural correctness" (391 a9-b2), and changing the name of something means somewhat to change the nature of that thing. ${ }^{15}$

In the case of $\delta$ ó $v 01 \alpha$, Socrates appears to be saying that in order to grasp its

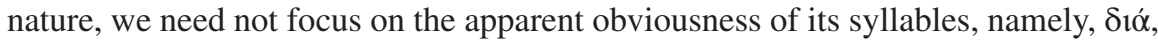
"through," and vóos, "intellect," "reason," which comes to mean "through the intellect" (Chantraine, 2009) or, within the theoretical context of the Republic, the capacity of immediate, nondiscursive, intuitive comprehension of the intelligible

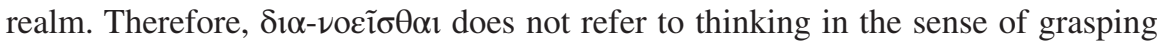
immediately and without doubt the nature of beings. It is rather $\delta 1 \alpha-\lambda \varepsilon \varepsilon_{\varepsilon} \sigma \theta \alpha 1$, in other words, "through $\lambda$ ó $\varsigma^{\circ}$ " or "traveling, crossing, finding a path/threading your

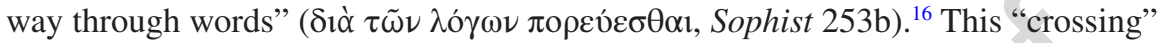
or "wandering" consists of the soul asking itself questions and answering them itself, affirming and denying. Put another way, thinking represents wandering about through $\lambda$ ó ${ }_{0} \varsigma,{ }^{17}$ to explore it in an indiscriminate manner. Given the inherently multiple and disseminated nature of $\lambda$ ó $\gamma o s$, thinking is thus defined as a creative and exploratory activity.

However, a more accurate translation would be "carrying on a discussion" or "talking things through." This rendering has the advantage of taking $\delta 1 \alpha \lambda \varepsilon \dot{\varepsilon} \varepsilon \sigma \theta \alpha 1$ as a nontechnical term. Plato is referring here to a more common and less methodical process than dialectic in the Republic (531c-535a). One argument for this reading can be found, as we have already seen, in Plato's very choice of words: he describes $\delta 1 \alpha \nu$ oє $\sigma \theta \alpha 1$ as $\delta 1 \alpha \lambda \varepsilon \dot{\varepsilon} \varepsilon \sigma \theta \alpha 1$. Or, in the context of the Republic, "dialectic" explic-

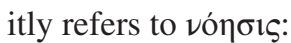

In the same way, when anyone by dialoguing $(\delta 1 \alpha \lambda \varepsilon \dot{\varepsilon} \varepsilon \sigma \theta \alpha l)$ attempts through reasoned/rational discourse ( $\lambda$ ó ${ }^{\circ} \varsigma_{\text {) }}$ without sense-perception towards what-eachthing-itself-is and does not give up before he grasps what-good-itself-is by means of intellection ( dialectic (

This is the "power of dialectic-dialogue $(\delta 1 \alpha \lambda \varepsilon \dot{\varepsilon} \varepsilon \sigma \theta \alpha \mathrm{l})$ " (511b): "to give an account of the being of each thing" (534b) and of the Good "according to truth and

\footnotetext{
${ }^{15}$ See, for the role of "voicing" the words differently and of searching through their "phonic matter" in Plato's Cratylus, Année (2011, pp. 1-45). Magali Année claims that we cannot understand Platonic etymologies in the Cratylus by way of the comparative grammar and our separation between "oral" and "written" language (p. 3), because they are relevant for a specific way of understanding language, namely, based on the "sound rhythm" of the Greek language (p. 2). In ancient Greek, the way we are voicing words creates a kind of "underlying meaning" (signification sousjacente) of language (p. 2). Voicing means decoding, encoding, and re-encoding language (creating meaning) in order to establish a kind of "particularly language" (p. 5). The way language weaves sounds together is the way we need to weave it anew-as a sumploké ("weaving together")—in order that new meaning arise.

${ }^{16}$ The vóos is thus eliminated from the "etymology" of thinking. This marks a considerable difference from the "mainstream" Platonic view of thought.

${ }^{17}$ I am referring here to M. Dixsaut's notion of errance, "wandering/erring" (see Dixsaut, 2000, pp. 185-190).
} 
what-is (oủ $\sigma i \alpha)$ rather than according to opinion and what-seems ( $\delta$ ó $\xi \alpha)$ " (534b-c, after Kahn, p. 296). The kind of dialogue Plato is referring to in the Theaetetus and the Sophist is, however, centered on questioning and answering and ends in $\delta$ ó $\xi \alpha$; and it does not suppose, in the two relevant passages at least, intellection, truth as a criterion and the (contemplation of the) Forms. It is the kind of dialogue which can put to the test different accounts of knowledge without being able to tell at the end what knowledge in itself is but only to have a true opinion about it. The soul's inner silent dialogue appears to be closer to informal conversation than to dialectic. It does not mean "to ask and answer questions in the most scientific way" (534d) or a rule-governed activity. It does however appear to require philosophical education or familiarization with different philosophical questions. Hence, another reason for distinguishing the inner dialogue from dialectic is that the latter is a systematic and methodical activity imposed on the philosophical search, whereas the former represents the very nature of the philosophic thought-community.

But let us now briefly return to the way the new theory of thought is presented by Socrates and the Visitor and then to the way it is received by Theaetetus. What, I think, raises some difficulties is, firstly, the fact that Theaetetus doesn't seem to have any problem in grasping the meaning of Socrates' or the Visitor's description (Theaetetus 190a8; Sophist 263e-264b). He doesn't ask for further explanation, and the matter seems well-known and obvious. Secondly, in the Theaetetus, Socrates, unlike the Visitor in the Sophist, presents his idea "in all ignorance" as it appears "subjectively" to him (189e8-9). Some commentators were led to believe that this means that the definition is purely nominal, i.e., it does not bear on the essence of the thing defined but on its name; and its "content" or "referent" may change according to the representations each of us has of thinking (Dixsaut, 2000, p. 48). Nevertheless, as we have already shown, the change in denomination should not be taken lightly or as innocent. Moreover, this does not explain why Theaetetus so readily agrees and understands Socrates "definition," given that at other moments in the dialogue, he does not hesitate to ask Socrates for clarifications $(152 \mathrm{~d} 1,154 \mathrm{~b} 10$, $164 c 3,7,199 \mathrm{c} 12,201 \mathrm{a} 6$, etc.).

I argue that Socrates, by renaming "thinking," is actually accomplishing two things at once: he evokes a common experience that all Greek culture, from Homer to the present time, shares and knows, and, at the same time, he is surreptitiously

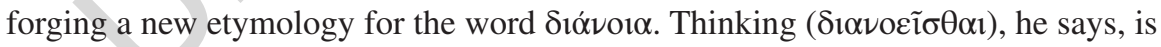
fundamentally "having a dialogue" ( $\left.\delta 1 \alpha \lambda \varepsilon_{\varepsilon} \gamma \varepsilon \sigma \theta \alpha 1\right)$. This doesn't amount to saying that all thinking is or should be dialogical in that sense but that he's talking about his idea and the "picture" he has about thinking. And yet, this does not necessarily mean that Socrates is expressing his personal/subjective view about thinking. Socrates, as we know, is in Plato's dialogues more than this particular individual, the historical Socrates. He is a character that usually stands for the embodiment of philosophy. ${ }^{18}$ His (objective) view on the matter may thus be taken as something almost prescriptive about philosophical thought.

\footnotetext{
${ }^{18}$ See, for example, Blondell (2002) and Loraux (1982).
} 
But what is so special about Socrates's description of thought, also restated by the Visitor in the Sophist? Isn't he simply using the model of the empirical dialogue, by removing the elements of orality and of the presence of the other, and applying it to thought? ${ }^{19}$ Isn't he talking about a form of self-sufficient reflection necessary to all philosophers? ${ }^{20}$ If that is the case, then it seems that Plato finally found a form of perfect, ideal, and authentic dialogue, with all the advantages and none of the frustrations of real-life conversation. ${ }^{21}$ No more non-compliant interlocutors and intellectual incompatibility, because everything happens internally, in a world directed entirely by the individual philosopher himself according to his rules. And if when conversing with someone else, "one can always pretend to be asking or answering questions, this would be absurd when talking to oneself” (Dixsaut, 2000, p. 53), because one is always honest toward oneself, and, facing oneself, one can never pretend.

I have two general objections to make to this type of reading. The first one concerns the fact that Plato did not choose to represent or depict this so-called ideal (or paradigmatic) dialogue in his writings. Because that type of dialogue is nowhere to be found: inward or outward. We never find descriptions of Socrates (paradigmatically and) explicitly talking with himself. ${ }^{22}$ This is not the same as saying that we cannot find allusions to a form of Socratic "solitary" reflection or inner dialogue. ${ }^{23}$ What are we to make of this? Socrates has conversations with himself, yet these conversations are in no way more truthful or authentic than his conversations with others. So, maybe Plato is showing what conversation (internal or external) ought to $b e$ : the only way of having a real dialogue is by taking into account other positions, by bringing them together in a responsive relationship, and by accepting the imperfections, the interruptions, the unwillingness, arrogance, and stubbornness to change one's point of view as a contribution to objectivity.

The second objection is that the silent dialogue is, in a certain sense, a form of internalized social conversation, "an internalization of the content and patterns of interpersonal discourse" (Gill, 1996, p. 47). As such, it comes with most of the difficulties and flaws of social dialogue, as it also comes with its advantages, namely, the multiplicity of different "voices" or perspectives. Dialogic thought is therefore more likely about preserving the plurality and communal aspects of interpersonal conversation even when somebody is by himself.

This would be the general outlook. If we look now in more detail at the two passages, we can notice that the image of dialogic thought seems more complicated

\footnotetext{
${ }^{19}$ This is what Dixsaut (2000, p. 50) thinks. See also Long (2013) for a similar reading. ${ }^{20}$ As Long (2013) thinks is the case.

${ }^{21}$ As Dixsaut (2000) and Long (2013) think is the case.

${ }^{22}$ The case of the Hippias Major (286c, 293d-294e; 298b; 297e-300b) is somewhat controversial (see Long, 2013; Woolf, 2008). Even if it is Socrates who is having a conversation with himself, the dialogue represents this conversation as any other ("Socratic") dialogue and not as a form of introspective reflection.

${ }^{23}$ See, for example: Apology 21d; Charmides 166c; Socrates' philosophical "autobiography" in the Phaedo 96a-102a; Socrates" "strange behavior" in the Symposium 174d, 220c-d; etc.
} 
than that. I'm referring here to the distinction between an internal and an external dialogue. Plato doesn't make this distinction, and the word "internal" or rather

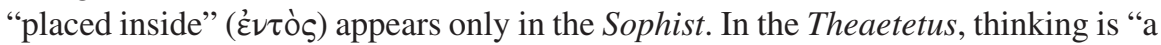
talk ( $\lambda$ ó $\gamma \circ \nu)$ which the soul has with itself about the objects under its consideration," and this means in fact $\delta 1 \alpha \lambda \varepsilon \dot{\varepsilon} \gamma \varepsilon \sigma \alpha \alpha$, "carrying on a discussion," in which "it asks itself questions and answers them itself, affirms and denies." However, at some point, the soul arrives at something definite, and "it affirms one thing consistently

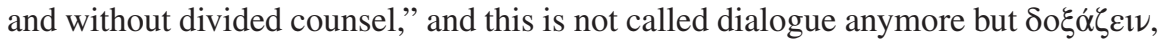
"having a belief," which is identical to $\lambda \varepsilon ́ \gamma \varepsilon ı$ ("speaking"). We thus have dialogue, on the one hand, and belief, on the other. The moment of having a belief seems to stand for the cessation of dialogic thinking. This is one distinction. The other one is between the belief thus reached or the speech ( $\lambda$ ó $\gamma o v$ ) which "is not addressed to

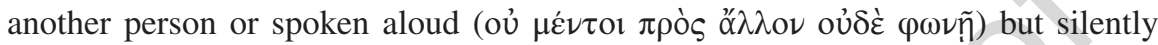
( $\sigma \vdash \gamma \tilde{n})$ addressed to oneself" (190a6-7) and the belief accompanied by sound and addressed to someone else.

In the Sophist, the description is couched in different terms, making the distinc-

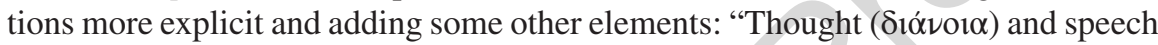

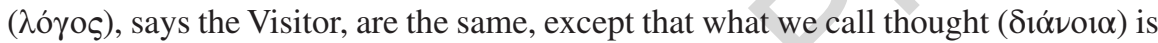

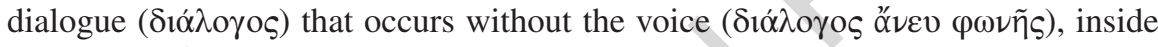

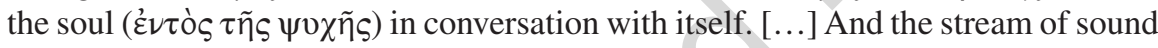

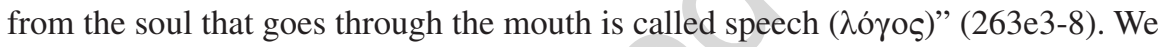
find out that dialogic thought and speech are not identical but of the same kind,

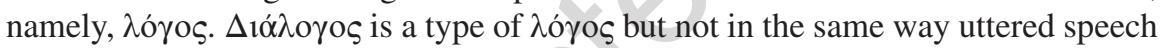
is $\lambda$ óyos, i.e., doxic $\lambda$ óros. The dialogue "placed inside the soul" occurs "without sound or voice," but speech is always uttered, it is something that is "breathed out." Not all speech is thought or dialogue, but all thought can become speech when it is accompanied with sound or when it is exteriorized. Furthermore, the $\lambda$ óyos that is exteriorized, "breathed out," is not the dialogue but its "conclusion," i.e., the $\delta$ ó $\xi \alpha$. The belief marks the cessation of the conversation, the moment when the soul doesn't doubt anymore.

So, silent dialogue is relatively distinguished from silent belief and from uttered speech. Nothing is said about the relationship between the soul's inner dialogues and interpersonal dialogue. Plato's silence on this should not be taken as indicative of any kind of dichotomy. The social dialogue is not an imperfect embodiment of an ideal internal dialogue. I don't think this is what Plato is suggesting here. When talking about distinctions, one should not have in mind absolute or metaphysical distinctions. If we consider a third passage about the dialogic thought that occurs in the Philebus (38c2-e7), we notice that the silent conversation the soul is carrying with itself might also be taking place, aloud, with someone else, without changing in any way its nature or its "authenticity." The Philebus illustrates the way thinking takes place. It presents the situation where someone, "who cannot get a clear view because he is looking from a distance," tries "to make up his mind about what he sees." Hence, he starts to ask himself questions and tries to find an answer, but he might as well say it out loud, if he were in someone's company, it would not change 
anything. And, finally, he might either get it right or be mistaken about what he is seeing. Either way, he will have a belief (true or false) about it.

So, there isn't any valorizing separation between silent dialogue and the uttered one; dialogic thought isn't a sort of ideal dialogue or something that guarantees "getting things right." The fact that the dialogue occurs in the soul does not bestow any special qualities upon it, like authenticity, originality, veracity, sincerity, or even privacy. And there doesn't seem to be any privileged and infallible access of the individual soul to it. At least, Plato isn't suggesting any of this. Thinking is not for Plato some mysterious, peculiar, and immaterial process that gets its virtues from taking place inward and by being the basis of linguistic expression. In a way, think-

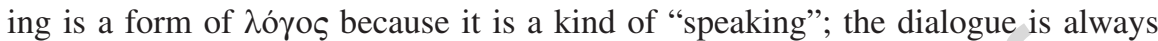
putting something into words, in a certain language, a "weaving of name and verb

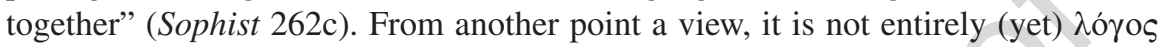
because it is not either (simple) discursive reasoning or speech in the sense of affirming or denying one definite thing but "weaving" together of question and answer, "aimlessly" wandering about, finding the right path, losing it, and start looking for it anew.

\subsection{The History of the Notion of Inner Dialogue. The Augustinian Moment or How Thinking Turns into a "Spiritual" and "Inner Private" Process}

Where does the idea that thinking is the phenomenon which occurs in the innermost and ineffable part of the soul, in a space so private and authentic that it represents, exhibits, and even constitutes one's truest self; in a place where there are no means to elude thinking by oneself, to avoid honestly asking questions to oneself and answer them sincerely come from? I argue that, even though there is no precise magical moment when this notion came to life, it doesn't seem to come from Plato, because it presupposes a series of distinctions unknown to Plato and to the Greeks in general. I am referring to the one between inner world/life and external world (cf. Burnyeat, 1982) or between inner-authenticity and external-inauthenticity or even self and community.

The Platonic notion was informed and reformed within the subsequent philosophical tradition by the debate around the relationship between thought and language. It would thus be about the identity between thought ( $\delta 1 \alpha$ ó $\alpha 1 \alpha)$ and language

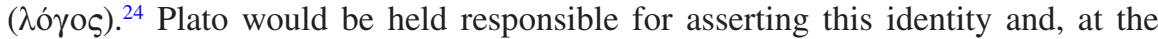
same time, for using it to differentiate the mental/internal language or discourse from the uttered (oral or written) one. Plato's image of thought became the doctrine of internal and external discourse/language.

${ }^{24}$ See Chiesa (1992, pp. 15-30), and Panaccio (1999). 
It seems that the Platonic dichotomy between internal and external language and the Aristotelian trichotomy between letter, sounds, and thoughts or states of mind in De Interpretatione are at the basis of the medieval conceptual framework of the three types of human language: internal language, oral language, and written language (Chiesa, 1992, p. 16). The internal language is to be understood in this context as a universal mental language, distinct from the oral and the written, prior to and independent of any particular language. According to C. Chiesa, there are four important moments in the Ancient tradition of "internal language": the Platonic moment; the Aristotelian one; the Stoic one when the distinction between $\lambda$ ó $\gamma \circ$

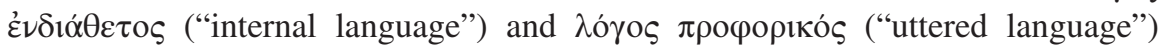
becomes current in philosophical debates; and, finally, the Porphyrian synthesis of these different elements that engenders the Medieval model of three discourses (p. 16). But, even more important for Chiesa is that, throughout this time, the theme of "internal dialogue" becomes increasingly autonomous, referring less to the Platonic context and becoming more of a philosophical banality related to the polysemy of the notion of $\lambda$ ó $\gamma$ os, meaning both "reason, reasoning" and "speech, language." Internal dialogue becomes a part of the "koinè conceptual language" and knows "different, and even contradictory, interpretations" (pp. 17-18).

Given how I have construed Plato's theory so far, its so-called founding role in this tradition may seem rather forced upon it than natural. But both modern and (many) ancient commentators have a particular interpretative framework that claims that one should easily recognize in Plato the theory of "relative identity between

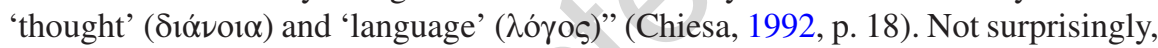
reading Plato's theory in this manner renders it problematic, from a general philosophical point of view, and within the Platonic philosophical system as well (p. 19).

In the first case, Plato makes what Wittgenstein would call a "category error" by identifying "thinking" and "speaking," instead of recognizing that "language is itself the vehicle of thought" (1953, §§ 329-330). ${ }^{25}$ In the second case, since Plato does not explain either the constituents and the content of the "language of the soul" or the relation between the uttered language and the language of thought, his theory cannot withstand criticism. Nonetheless, Chiesa thinks we can plausibly affirm, by taking into account the post-Platonic tradition, that for Plato the thinking soul is the source and origin of speech and that the internal dialogue is essentially different from its externalization (pp. 19-21). Even though internal language is structured as speech, it does not occur in a particular language; it is fundamentally "spiritual." This does not mean that, for Plato, "thought is interiorized language" but rather that "language is externalized thought." Put into modern words, "the relation between logos and dianoia is similar to the one between expression and content" (p. 21). Logos is nothing more than the contingent and external materialization of a universal spiritual content/meaning that happens or occurs entirely inside the soul. As a

\footnotetext{
${ }^{25}$ According to Chiesa (1992, p. 19), Plato would be thus responsible for a certain « mythologie de la pensée qui fait de celle-ci un processus étrange et mystérieux en la considérant à la fois comme un langage et comme un processus incorporel qui accompagne nécessairement l'expression linguistique ».
} 
result, Plato's theory, albeit a "strange" one within his philosophical system, does not exceed the "already common psychophysical dualism."

I claim, however, that this tradition and the way it was reconstructed by scholars today misconstrue Plato's notion of dialogic thought. We should rather try to understand its distinctiveness in contrast with the tradition it engendered. Three remarks are in order. Firstly, at the very basis of these interpretations is the idea that, beginning with Plato, thought has been conceived as language. ${ }^{26}$ But Plato is not really innovating on this matter. Thought has been seen as a kind of "speaking" or as "having a conversation with oneself" even before him, throughout Greek culture in general. ${ }^{27}$ The relationship between thought and language - and the fact that silent thought is not "universal" and "spiritual" but takes place in a given language, namely, ancient Greek-does not seem to be problematic for the ancient Greeks but rather an implicit cultural trait that need not be questioned.

Secondly, a common characteristic of this tradition is terminological homogenization. We find fewer traces of the "silent dialogue placed inside the soul" and more

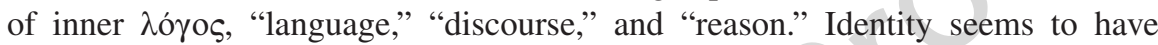
become absolute: the silent dialogue of the soul is nothing more than a mental language or "inner word" and "internal speech." And this is not without consequences for the interpretation of Plato. It equates the $\delta 1 \alpha \lambda \varepsilon \dot{\varepsilon} \varepsilon \sigma \theta \alpha$ of the Theaetetus and the Sophist with the $\delta 1 \alpha \nu$ $\tilde{\imath} \sigma \theta \alpha \mathrm{l}$ of the Republic, which is discursive thinking. ${ }^{28}$ However, dialogic thought doesn't mean either discursive thinking or conceptual thinking. ${ }^{29}$ It is neither simply propositional thought nor solely logical thinking, but rather dialogical, i.e., a continual to-and-fro movement from question to answer and from answer to question. In contrast with reasoning, which describes the necessary movement from premises to a conclusion, or the discursive mode that proceeds deductively from hypotheses to a conclusion, dialogic thought can wander, can err and stray from a given path, and it can even explore only for the sake of exploring. ${ }^{30}$ The dialogue ceases (momentarily) its "wandering" when it "stumbles on" $\delta$ ' $\xi \alpha$. In other words, the soul can arrive at something definite "either by gradual process or a sudden leap." Thinking does not necessarily wander about in order to find the right path. It wanders about so that it can know all possible paths. When it wanders, it

\footnotetext{
${ }^{26}$ This is not the case for all readings. Gadamer (1989), for example, claims the contrary: Plato would actually be the one responsible for recognizing the separation between language and thought and that it is only beginning with Augustine that we started conceiving their unity and identity. But the essential problem is that he, as other authors, misreads Plato's theory as being about the relation between thought and language, whereas, I think, for Plato such a question is not even conceivable. Because for the ancient Greeks there is no conception of a preverbal and spiritual thinking that lies at the foundation of language, only thinking as a kind of speaking.

${ }^{27}$ See Gill (1996) and Onians (1988).

${ }^{28}$ For a more extensive treatment of the different types of thought in Plato, see Dixsaut (2000, pp. 47-70).

${ }^{29}$ See, for example Frede (1989, pp. 20-49).

${ }^{30} \mathrm{I}$ am, once again, borrowing and radicalizing Dixsaut's notion of errance (2000, pp. 185-190).
} 
learns that it does not know the right path and that even if it comes upon it, it was only by "accident" (by $\delta \delta^{\xi} \alpha \alpha \dot{\alpha} \lambda \eta \hat{\eta} \varsigma$ ) that it happened. ${ }^{31}$

Finally, and most importantly in my view, one of the leitmotifs of the story of mental language is the internal-spiritual character of thought. But what if the notion of interiority has a different meaning for Plato than for the Christian-modern outlook? Let us consider the fact that, as M. Burnyeat observes, the division into the inner (subjective) world - the designated space where all subjective and introspective experience takes place - and an outer (objective) world does not seem to have anything to do with Plato and with the Greeks in general (1982, pp. 26-40). Hence, saying that Plato entertains the idea of a spiritual and internal thinking as the source and foundation of uttered speech or as that which organizes and explains through its categories the nature of the world, stands at least as proof of an anachronism. Thought, for Plato, "must be of something independent of itself," and it is "relative, essentially of something else" (pp. 21-22). It is thus incapable of any foundational task.

However, if our ideas of inwardness and interiority don't originate in Plato's philosophy, where do they come from $?^{32}$ As Philip Cary argues, the Western tradition of inwardness was inaugurated by Augustine's conception of inner life and his invention of the self as a private inner space (2000, 2011). Augustine's version of the soul's silent dialogue is the verbum interius, "inner word." The first distinctive feature of Augustine's inner word is that, unlike Plato's dialogue of the soul, it explicitly denies being about "the kind of thinking we do when we silently use the words of a particular language" (Cary, 2011, p. 192). ${ }^{33}$ The inner word is not only prior to sensible sound but also to imagined sound; it is intelligible and not sensible: "... the inner word is an intellectual word, the product of intellect in its love of vision [of God]" (p. 193). ${ }^{34}$ The second feature of the inner word is that it is introspective, namely, generated by the "active turning or conversion of the mind to itself, which puts itself directly in its own mental sight" (p. 193). The inner word represents the way the soul can understand itself by thinking about itself, by turning inward. And by this "journey inward," the soul gets in fact closer to the "ultimate inwardness of God" (p. 194). ${ }^{35}$ A third feature of the inner word is that it remains immutable and somewhat ineffable. Even if it "incarnates" in sound, it always remains in the soul, unchanged, whole in itself and, consequently, inadequately expressed.

Thinking is, for Augustine, a deep, inward, preverbal experience, an "experience of the divine that is too deep for words" (pp. 196-197). However, thinking still is a kind of speaking: "he who thinks speaks in his heart" (Augustine, On the Trinity, $\mathrm{XV}, 10,17)$. Except that there are two kinds of speech, "speeches of the heart" or

\footnotetext{
${ }^{31}$ See also Meno, $97 \mathrm{a}-\mathrm{b}$ for the role of true belief in the image of knowing the way to Larissa without having been there. The role of (true) belief in Plato would require a more detailed study.

${ }^{32}$ This question would require a more detailed account than the current paper allows it. I will limit my answer to a few distinctive features of Augustine's notion.

${ }^{33}$ Also, see Augustine, On the Trinity XV, 19.

${ }^{34}$ Because "the inner is higher, better, more intelligible, and closer to God than are external, sensible, and bodily things, including the sounding words of human language."

${ }^{35}$ Also, see Cary (2000, Chaps. 3 and 5).
} 
thoughts, and speeches of the mouth (XV, 10, 18). Furthermore, inwardly, these "speeches of the heart" are "also acts of sight, arising from the sight of knowledge... For when these things are done outwardly by means of the body, then speech and sight are different things; but when we think inwardly, the two are one" (XV, 10, 18). Thinking is a form of seeing and speaking at once. The "voice" of the heart has nothing to do with any particular natural language (linguae gentium), but it resembles the Divine Word (John I, 1) (XV, 10, 19). The silent dialogue thus becomes Word, an act of seeing and mostly listening somewhere deep inside the soul.

When the soul thinks, it journeys inwardly, and it grasps its own incorporeal nature and then discovers a "voice," a "voice" more profound and truthful than any human voice, the "deep voice" of Truth, of God, present within itself. And this "voice" speaks to the soul, teaches it, admonishes it, and transforms it. By means of the inward turn, one finds one's true self and God, who is separated from the soul but can only be found inside it. Augustine's search for God "requires the double movement, first in then up" (Cary, 2000, pp. 38-40; 117). It is the very inward turn - or "in the interval between the turning in and looking up"-that generates an inner space proper to the soul, "a whole realm of being waiting to be entered and explored" (p. 39).

There isn't any trace of Platonic dialogue left, because the multitude and diversity of "voices" is reduced to a single authentic and commanding voice, because the conversing is transformed in simple listening and learning. As Jean-Pierre Vernant claims, with the Christian thought of the third and fourth centuries, and especially with Augustine, ${ }^{36}$ "a new form of identity takes shape...: it defines the human individual by way of his most intimate thoughts and secret imaginings, nocturnal dreams, sinful drives, and the constant obsessive presence in his innermost heart of all forms of temptation" (1991, p. 332). Put another way, it defines the human individual by his capacity to observe and introspect his inner world, which becomes henceforth the very source of Truth and authenticity. This kind of individual "separates himself from the common herd and disengages himself from the social group only in order to set out in quest of his true self" and in the search for God; "the search for God and the search for the self are two dimensions of the same solitary ordeal" (p. 332).

\subsection{Plato and the Polyphonic-Koinonic Model of the Self}

If Plato did not have something similar to our notion of interiority, no idea about an immaterial "inside," about privileged access to a life and a world existing only inside our souls, hidden and mysterious, truthful and authentic, how should we then

\footnotetext{
${ }^{36}$ We should add that the Augustinian "inward turn" radicalizes with Descartes's discovery of an inward reality (as opposed to the external one). The interiority, conceived as the privileged space where conscious thought takes place or where the "I" "sees" and "hears" everything, is the source of all intelligibility, consciousness, truth, and self-knowledge (see also Burnyeat, 1982; Dennett, 1991, p. 107).
} 


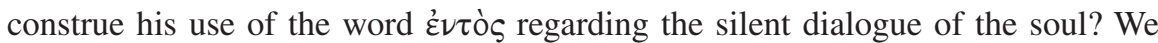
would still be tempted to ask exactly where this dialogue takes place. Only that the answer would be disarmingly simple and it may not require our own metaphorical language. I am suggesting here that the way, for example, the Stoics understood the

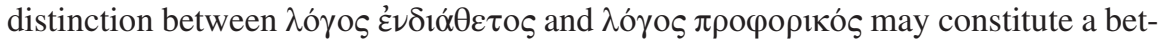
ter starting point for understanding Plato's theory. C. Chiesa thinks that the Stoics framed the distinction within a "strange monist outlook" (1992, p. 25). This may nevertheless be less "strange" for Plato than for us, and it may be "strangeness" which we should look for when understanding Plato.

The Stoics consider the internal/external dichotomy as referring to a "physical or local distinction." Thoughts are configurations (or physical states) of the material $\pi \nu \varepsilon \tilde{v} \mu \alpha$ (i.e., a breath-like substance); they are bodies the same way voice is a body. Although in Chiesa's view the internal language does not designate anymore, for the Stoics (as apparently, it did for Plato), "the mental and spiritual dialogue which the immaterial soul has with itself, but the air located in the trachea artery before getting out through the mouth in the form of sounds of the voice" (p. 25), and I claim this view may actually be closer to Plato's dialogic thought than we are inclined to believe. I am therefore saying that we should take the idea of internal localization literally. We could understand it in terms of material place, and not of some metaphorical "inside." Henceforth, the question of knowing where thinking takes place can only bear one answer, i.e., inside (and outside) our animated bodies.

One can easily see how this idea of "air" or "stream of sound" not-yet exteriorized could evoke Plato's description of thought in the Sophist. However, this more or less apparent link could hardly be considered as an argument for such a "strange" reading of Plato. The rest of my argumentation may seem to some speculative in nature due to the fact that the reasons I will give are rather implicit in Plato's dialogues and somewhat controversial.

A first clue can therefore be found in the Sophist, where the distinction of thought from speech seems to stand on the presence or absence of "sound": "[...] thought is dialogue that occurs without the voice, inside the soul in conversation with itself. [...] And the stream that flows from the soul through the mouth in vocal expression is called speech" (263e, transl. modified). It is worth noting that the "stream" comes from within the soul, goes through the mouth, and, only at this point, becomes accompanied by sound. Even if Plato conceives the soul as incorporeal, this does not suppose an immaterial inner space. The "stream" could only come from an embodied soul. It could, thus, well mean that Plato is referring here to a stream of air, although nothing is said explicitly about the presence of "air" or "breath," $\pi \nu \varepsilon \tilde{v} \mu \alpha$. It is possible that thinking and speaking both imply breathing or the same stream of air, only that the latter also involves sound. Nothing is said because it goes without saying. It is only alluded to. Hence, thinking and speaking may share the same material vehicle.

Moreover, in the Theaetetus, we can find another argument in favor of the "Stoic" reading. When discussing the three meanings of $\lambda$ ó ${ }^{\circ} \varsigma$, the first one that Socrates identifies is "making one's thought apparent through sound with words and phrases,

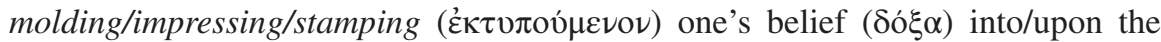


stream flowing through the mouth as if into/upon a mirror or water" (206d; translation modified). The language in this passage is strikingly similar to the Stoic's discussion of "impressed $\pi \nu \varepsilon \tilde{v} \mu \alpha . "$ But more importantly, it is not the image of one's belief (as in M. J. Levett's-revised by Myles Burnyeat-translation) that one impresses upon the "stream flowing [from the soul] through the mouth" but the very belief itself. The analogy with the mirror or water can be misleading here. It is not that belief is reflected in uttered speech as an object is reflected in a mirror or water, at is, in/through an image. It is rather that belief is impressed upon "the stream owing through the mouth" as an object is "impressed" upon the mirror or the water in which it is reflected, i.e., a material object leaves a mark in another material object. The language here used may reasonably lead us to believe that "thought," "belief," "speech," and the "stream flowing through the mouth" have the same breath-like nature. We can therefore safely assume that the same stream of air contains thought and speech, thought and sound. And that means that thought and speech are materially identical; otherwise, we will be forced to explain how can something incorporeal could be impressed upon something corporeal and why Plato does not make the "right-up-his-alley" distinction between incorporeal thought and corporeal speech.

Finally, we need to take into consideration the fact that, however innovative Plato's philosophy may be with respect to its cultural background, it is not implausible to still assume that he shares similar (and not identical) beliefs and views about thought and the soul with, for example, the Homeric Greeks or with some other predecessors. One important similarity is the fact that the early Greeks describe

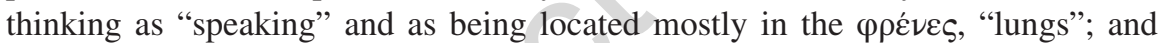
"deep reflection is [described as a] conversation of one's self with one's thumos or of one's thumos with one's self"'(Onians, 1988, p. 13). Thinking is thus physically located (although not limited to) somewhere inside the body and, most importantly, is associated or identified with physical processes or elements, such as breathing or rather something "vaporous" related to the blood. Therefore, the early (and some of the later) Greeks conceived what we today call abstract or immaterial entities, like thought and emotions, as material entities. Conceiving thought, speech, or emotion materially as breath or as some other bodily expressions did not mean for them as it usually means for us "thinking that the latter are epiphenomena or after-effects" but rather that they represent the one and the same process (Onians, 1988, pp. 52-3). ${ }^{37}$

If thinking is a type of speaking, then thinking follows the same path as speaking and, consequently, as breathing, i.e., the action of inhaling and exhaling. And one cannot look for the source of thinking "inside" or "outside" for it is the interplay between "inward" and "outward." It would be like saying that breathing is something done entirely inside our bodies rather than the process of inhaling and exhaling, or the process of moving air in and out of the lungs. Thinking, for Plato, does not therefore emerge internally, it is not a process entirely made inwardly and only

\footnotetext{
${ }^{37}$ See also Clarke (1999): “There is no 'ghost in the machine': the Homeric man does not have a mind, rather his thought and consciousness are as inseparable a part of his bodily life as are movement and metabolism" (p. 115).
} 
waiting to be uttered. The same way as speaking is not the simple exteriorization of a thought already made inwardly. For the early Greeks, as Onians argues, the association of thought with speaking and breathing means that speeches "come forth with the breath that is intelligence in them, they are parts of it, and the listener puts them, takes them, into his thumos, thus adding to his store, his knowledge. They pass from lung to lung, mind to mind" (p. 67 and pp. 69-70). ${ }^{38}$ Thinking is not entirely done in one place. It is about the dynamic of hearing and speaking, inhaling, and exhaling. That is why the separation of thought from speech should not be taken as absolute. When we speak, we don't stop breathing, and we don't stop thinking and vice versa. Thinking is conversing because thinking is speaking, and all of this is nothing but breathing. Air is what constitutes the corporeality of thinking.

Saying, though, that for Plato the "internal/external dialogue" is a question of physical distinction does not exhaust the issue. We still need to explain what exactly he means by silent dialogue of the soul with itself. A first remark that needs to be made is that, "internally" and "silently," the dialogue is not actually more monologic in nature than the interpersonal conversation. It is actual genuine dialogue and, furthermore, polyphonic dialogue. I'm not solely referring here to B. Williams ethical concept of "internalized other" (1993, Chap. 4). I actually prefer to call this internalized somebody by the name of "voice." ${ }^{39}$ By doing so, I think we can avoid referring to an internal arena/space/world/theater where one can accommodate, "see," and "hear" the "internalized other." Because the notion of voice evokes, on the one hand, an external source, the fact that it comes from somebody else or from somewhere else, and, on the other hand, a voice is something that needs to be uttered in order to be heard. The inner dialogue thus represents "internalization," i.e., hearing of the voices of others, and "externalization," i.e., uttering or speaking. The inner dialogue resembles the inspiration-expiration process of breathing.

But, where are the "voices" to be found in the two passages about silent dialogue? If anything, there appear to be no voices, only the individual soul with itself. In the Theaetetus, it is explicitly stated that "belief' [is] a speech which is not

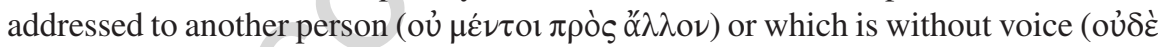

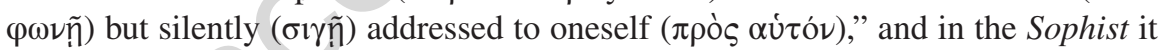
is even more clearly said that what "we call thought is dialogue that occurs without

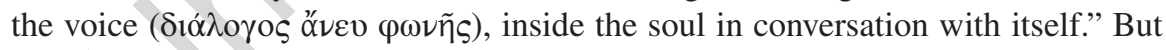

\footnotetext{
${ }^{38}$ Thus, "the words, thoughts that issue forth, portions of it, are feathered, 'winged' like birds ... to the hearer. Unspoken, kept in the phrenes, they are "not winged'." Onians thinks that these early conceptions may have suggested to Plato the image of the mind as a cage full of birds in the Theaetetus, 197c. Moreover, the belief that thoughts come from (or are breathed forth from) and are taken into the lungs or the chest can also be found in Plato's Phaedrus (235c) and Republic (III, 411a) (p. 71)

${ }^{39} \mathrm{My}$ concept of voice is based on different (heterogeneous) ways of understanding it in separate fields of knowledge. I should mention the researches about the dialogic mind in cognitive sciences (Fernyhough, 1996, pp. 47-62), the studies about polyphony in literature (especially M. M. Bakhtin's works), and the interpretations of some Platonic scholars (Corrigan \& Corrigan, 2004). But, one of the most significant, yet implicit, influences was exerted by Julian Jaynes's book, The Origin of Consciousness in the Breakdown of the Bicameral Mind (1976).
} 


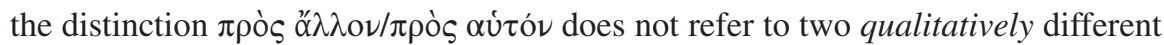
types of address: one authentic and the other inauthentic and one subjective or introspective and the other interpersonal. It only states the fact that inner conversation is not directed toward a flesh-and-blood individual present before us. It is directed toward the soul itself. Yet, even if thought is the dialogue addressed to oneself (or for oneself and with oneself), it may well still be polyphonic. Polyphony does not imply that the soul addresses another person. It only supposes that different voices converse ("within" one's soul) with each other.

What I mean by "voice" is an individualized, yet objective, perspective on the matter at hand. Every voice stands for a different perspective on reality or for a different "cognitive interest." ${ }^{40}$ In other words, every voice is the concrete and physical manifestation of a particular "ideology." 41 This kind of "voice," which I claim is an ineluctable voice that is heard, is first suggested to in the expression "without

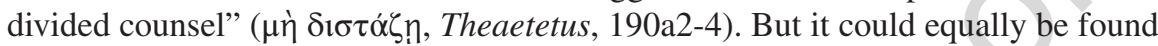
in the idea that the soul asks itself questions and answers them itself, it affirms and denies. By "internal dialogue," Plato, thus, apparently means to describe the inherent duality of the thinking soul or the fact that when one thinks the soul is divided into two: the part that questions and the part that answers, the one that affirms and the one that denies. However tempting it may be to conclude that Plato is referring to the "divided self" or to the intrinsic duality of the soul, I argue that we should tread carefully this logical leap. Just because the soul is somewhat divided into question and answer or, I would rather say, caught in the give-and-take of question and answer, that doesn't mean it is divided into two "individuals," questioner and answerer. In other words, the silent dialogue doesn't consist in only two "voices" or two sides that converse. As the conversations depicted in the Platonic dialogues and as the "dramatic" elements of Plato's work often prove, ${ }^{42}$ the (internal) dialogue embodies multiple "voices"; therefore, it is polyphonic in nature. It is indeed true

\footnotetext{
${ }^{40}$ The expression is used by Blachowicz (1999). I also find it useful for explaining such examples as the one about dialogic thought in the Philebus, where it seems like the "voices" stand for the "voice" of (sensible) experience and the voice of "memory" or "reason."

${ }^{41}$ See Bakhtin (1981) and Fernyhough (1996, p. 49): "[ideology] represents the instantiation of a particular perspective on the world, together with each of its ontological, axiological, conative and motivational elements."

${ }^{42}$ See Corrigan and Corrigan (2004) and Blondell (2002). Corrigan and Corrigan's view of polyphony is concerned with the interplay between the "dramatic" and the philosophical aspects within Plato's works and, consequently, with the overall construction of each work. Each dialogue is a "drama of many voices and many different characters (...). In a sense, each new voice adds another angle to all the voices of the drama" (p. 189). But, it is also "a drama of many different genres (...) all of them brought together into what is essentially a new artistic and philosophical form, that is, an experimental form of dialogues and characters nestling within one another, and not only this, but addressing, commenting, criticizing, reshaping, and trying each other." There is, thus, in Plato's dialogues a pervasive "dependence on the voice of the other," where "the other" can stand for a character and a voice, but also for a different kind. Polyphony does not simply represent "doublevoicedness" or diversity of voices, but "real dialogue pervaded by the speech of the other" or dialogic multi-voicedness.
} 
that duality is the minimal condition for dialogicity, but this is not what fundamentally defines the silent dialogue or the Platonic dialogues as a whole.

The notion of voice thus has some essential advantages. It is particular, individualized, and objective at the same time. As we can repeatedly notice in the dialogues, ${ }^{43}$ it is the voice of a distinct somebody with his idiosyncrasies and specific beliefs. It is also the voice of something, as it stands for a certain perspective on reality, for a certain philosophical outlook and ethical type. The subjective features of the "voice" are philosophically, i.e., objectively, transfigured and vice versa. ${ }^{44}$ In other words, the subjective in Plato's dialogues, i.e., the characters of the speakers, is never accidental to the objective aspects, i.e., their perspective, vision, and "voice." To every voice is assigned an individual face and vice versa.

The concept of voice equally enables the blurring of boundaries between internal and external aspects of the silent dialogue. On the one hand, the soul thinks multiple voices are in conflict within it. On the other hand, the voices are not completely internalized in the sense of being an integral part of a unified soul, a simple voice in one's head. They are not, as we moderns might experience it, coming from within. They are "strange" and "different," traveling from "outward" to "inward," and they are "inspired" or, without the quotation marks, breathed in and breathed forth. However, the voices are not simple instruments of thought but the very "matrix of thought" (Renaut, 2013). Voices form, in-form and trans-form thought; they are the medium, the physical and "ideological" vehicle of thought.

I am thus arguing for a "polyphonic self" rather than a "self in dialogue" (Gill, 1996). Because the dialogic relationship "within" one's self does not amount to a conflict or debate between two types of reflection, two types of virtue, and two tendencies or faculties but to a coming-together of a plurality of "voices." In this "coming-together," there is conflict, but most importantly, the "voices" are brought into a responsive (and not necessarily harmonious) open-ended relationship. The polyphony of Plato's dialogic thought is not simple "double-voicedness" in the sense of "diversity of voices" but "real dialogue pervaded by the speech of the others" (Corrigan \& Corrigan 2004, p. 197).

Thought is polyphonic and dialogic. It is never about who wins the confrontation (within the soul) but about how many voices are really taken seriously, examined, and finally never completely rejected, because the voices never merge into a final, definitive single perspective. In polyphonic dialogue, the voices "interanimate each other" in their opposition and interaction, and the dialogue is always preserved in its open-endedness and indeterminacy (Bakhtin, 1981, pp. 353-4). Thinking is therefore an inconclusive process, always-in-the-making. Thinking is not a self-asserting

\footnotetext{
${ }^{43}$ See, for the notion of character and the relationship between character and "voice," Blondell (2002) and Corrigan and Corrigan (2004).

${ }^{44}$ Blondell (2002) argues convincingly that one of Plato's major concerns throughout the dialogues is the interplay between multiplicity and unity, individuality, and objectivity. However, I don't think, as Blondell does, that Plato is looking to compel unity and objectivity to transcend multiplicity and individuality, but rather to integrate the two conflictual aspects into philosophical dialogue.
} 
and private-authentic process but a way of constantly revisiting, revising, and better founding the ethical life of the community. Thought as dialogue represents the very dynamic of the shared life-word, the "stream of meaning flowing among and through and between us" (Bohm, 1996, pp. 6-7).

Plato's understanding of selfhood is therefore not only polyphonic but equally koinonic in that it conveys a form of togetherness or "communion" that doesn't invalidate individuality (as a source of disharmony and conflict) but brings it into a responsive relationship. We have become accustomed to the idea that the culture of Ancient Greece with its sense of community and selfhood, in strong contrast with our own individualistic and subjective outlook, is impersonal and objective in nature. In other words, the individual is defined by the degree of participation in the shared life and in the shared practices and that objective knowledge is conceived as a sort of subjective-and-intersubjective-free single block of truth waiting to be discovered..$^{45}$

But koinonia is something more than fellowship or communion through participation. There is no real tension between individuality and community in the modern sense. However, this doesn't mean, as Gill thinks, that for the Greeks community resembles a shared -I instead of the sum of all individuals (Gill, 1996, pp. 348-49). Understanding it in this manner, we still fail to discard the notion of a "unitary center of consciousness." Because in this case, it will be the community as a whole that reflects, as a Cartesian ego but at a higher scale, on the best possible human life. I rather prefer to illustrate the conflict inherent in the Greek community as one between different micro-koinoniai. Let us remember that for Plato koinonia does not exclusively constitute human condition but also logos and reality as such. ${ }^{46}$ It is a sort of attuned coming-together of different and often contrary elements. And by attunement, I do not mean homogenization but the bringing into "dialogue" of different elements.

Therefore, micro-koinonia stands for a polyphonic unity. The Greek's home or family and friends represent different micro-koinoniai; the life of the community is constituted by micro-koinoniai: the agora, the theater, and the symposium. But most importantly for Plato is that the individual soul is in itself a micro-koinonia. And, consequently, every Platonic dialogue can be seen as being one. It is likely that the notion of an ideal community in the sense of a perfectly harmonized whole that reflects on different issues and concerns with itself is something the Greeks knew nothing about. The community as a whole is only the "conversation" between (or the coming together in a responsive relationship of) different microcommunities. And every microcommunity in turn is dialogic in nature. Thus, maybe the "place"

\footnotetext{
${ }^{45}$ Cf. Ch. Gill (1996) and Gill and McCabe (1996). Certainly, Gill stresses the idea that objective knowledge depends on participation in certain types of shared activities, and it can only occur in concrete and specific dialectic encounters. Nevertheless, objective knowledge still looks, in his view, like something already given and waiting to be discovered, and the participative aspect of the search of knowledge is still defined in contrast with the modern view that truth is attainable by the individual through isolated reflection.

${ }^{46}$ See the discussion in the Sophist (250-253) about the five kinds and the example of music and speech as forms of koinoniai. And see also Parmenides, 127-136.
} 
of objective knowledge could be found in the very dynamic of koinonic polyphony, as something that is always in the making and open-ended, and not either existing somewhere beyond the individuals and beyond this world, already made waiting to be discovered or intersubjectively created.

\subsection{Conclusion}

Understanding Plato's dialogic thought on the model of the "koinonic polyphony" allows us to elude the specific modern tension between subjective and anti-subjective ways of explaining conscious thought and selfhood. Given that today all "objective" attempts must always distance themselves from and situate themselves in opposition to the inherent and prevailing "subjective-individualist" view, it will be more appropriate to qualify it as anti-subjective and non-individualist. Saying that thought is, for Plato, polyphonic and "communal" frees us from supposing a set of dualist oppositions: internal/external, subjective/objective, self-centered/other-centered, and self-conscious/unselfconscious.

I would characterize Plato's thinking with an ancient saying of uncertain origin (most probably to be attributed to Arius Didymus): "Plato is a man of many voices (polyphonos), not of many beliefs (polydoxos)."47 The saying should not be understood as meaning that Plato had only one unitary doctrine and many ways of presenting it; but as claiming that for Plato objective knowledge or truth resides in polyphony, in the multiplicity of voices in dialogue and not in the many beliefs in which the dialogue ends. Doxa is always limited and provisional and therefore less pertinent than the many indomitable and perennial voices that constitute thinking. On the other hand, doxa represents the moment when doubt ends. It thereby represents only one way that something can be said and understood. While the voices preserve doubt, they are dynamic because the same voice can say different things in a different context, and the many voices can say different things in the same context. This doesn't, however, mean that polyphony is the way the philosopher proofreads the multiplicity of logoi. Polyphony does not guarantee truth, but it does guarantee the indiscriminate exploration of logoi, and therefore "investigating the truth of things by means of words." And this may be the only (partial) truth human beings have access to.

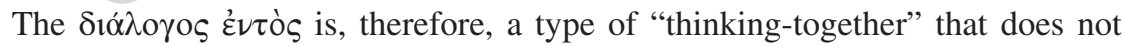
exclude the fact of being someone physically, psychologically, and ethically distinct, but it may exclude the idea of conceiving oneself as having a private and ineffable (true) self or an inner private life. Plato's idea of selfhood doesn't propose a fundamentally "private" entity, but a psychophysical distinct entity constituted by polyphony. And the community doesn't represent the sum of all individuals or a "shared-'I"" but the "conversation" between multiple and different microcommunities. Instead of replacing the notion of subjective unity by that of duality, or the

${ }^{47}$ Cited by Stobaeus 2.55.5-7. 
notion of autonomy by that of participation, we should take into account the polyphony that constitutes altogether $u s$ and them. And it is exactly this aspect that certain

\section{References}

Alderson-Day, B., \& Fernyhough, C. (2015). Inner speech: Development, cognitive functions, phenomenology, and neurobiology. Psychological Bulletin, 141(5), 931-965.

Alderson-Day, B., Weis, S., McCarthy-Jones, S., Moseley, P., Smailes, D., \& Fernyhough, C. (2015). The Brain's conversation with itself: Neural substrates of dialogic inner speech. Social Cognitive and Affective Neuroscience, 11(1), 110-120.

Année, M. (2011). Le "Cratylisme" de Platon: Le Cratyle comme réappropriation philosophique du fonctionnement phonico-pragmatique dela langue poiétique archaïque. Journal of Ancient Philosophy, 5(1), 1-45.

Augustine. (2002). On the trinity (G. Matthews, Trans.). Cambridge, England: Cambridge University Press.

Bakhtin, M. (1981). The dialogic imagination (M. Holquist Trans.). Austin, TX: University of Texas Press.

Barton, D. (1999). The Theaetetus on how we think. Phronesis, 44(3), 163-180.

Blachowicz, J. (1998). Of two minds. Albany, NY: State University of New York Press.

Blachowicz, J. (1999). The dialogue of the soul with itself. In S. Gallagher \& J. Shear (Eds.), Models of the self (pp. 177-200). Thorverton, England: Imprint Academic.

Blondell, R. (2002). The play of character in Plato's dialogues. Cambridge, England: Cambridge University Press.

Bohm, D. (1996). On dialogue. London, England: Routledge.

Burnyeat, M. (1982). Idealism and Greek philosophy: What Descartes saw and Berkeley missed. The Philosophical Review, 91(1), 3-40.

Cary, P. (2000). Augustine's invention of the inner self. Oxford, England: Oxford University Press.

Cary, P. (2011). The inner word prior to language. Philosophy Today, 55(2), 192-198.

Chantraine, P. (2009). Dictionnaire étymologique de la langue grecque. Paris, France: Klincksieck.

Chiesa, C. (1991). Le problème du langage intérieur chez les Stoïciens. Revue Internationale de Philosophie, 178, 301-321.

Chiesa, C. (1992). Le problème du langage intérieur dans la philosophie antique de Platon à Porphyre. Histoire Épistémologie Langage, 14, 15-30.

Clarke, M. (1999). Flesh and spirit in the songs of homer. Oxford, England: Clarendon.

Corrigan, K., \& Corrigan, E. (2004). Plato's dialectic at play. University Park, PA: Pennsylvania State University Press.

Cossutta, F., \& Narcy, M. (2001). La forme dialogue chez Platon. Grenoble, France: J. Millon.

Dennett, D. (1991). Consciousness explained. Boston, MA: Little, Brown and Company.

Dennett, D. (1992). The self as a center of narrative gravity. In F. Kessel, P. Cole, \& D. Johnson (Eds.), Self and consciousness: Multiple perspectives (pp. 103-115). Hillsdale, NJ: Erlbaum.

Dixsaut, M. (2000). Platon et la question de la pensée. Paris, France: J. Vrin.

Duncombe, M. (2016). Thought as internal speech in Plato and Aristotle. Logical Analysis and History of Philosophy, 19, 105-125.

Fernyhough, C. (1996). The dialogic mind: A dialogic approach to the higher mental functions. New Ideas in Psychology, 14(1), 47-62.

Fernyhough, C. (2008). Getting Vygotskian about theory of mind: Mediation, dialogue, and the development of social understanding. Developmental Review, 28(2), 225-262. https://doi.org/ 10.1016/j.dr.2007.03.001 
Fernyhough, C., \& McCarthy-Jones, S. (2013). Thinking aloud about mental voices. In Hallucination (pp. 87-104). Cambridge, England: MIT.

Frede, D. (1989). The Soul's silent dialogue a non-aporetic reading of the Theaetetus. Proceedings of the Cambridge Philological Society, 35, 20-49.

Gadamer, H.-G. (1989). Truth and method (2nd revised ed.) (J. Weinsheimer \& D. G. Marshall, rev. Trans.). New York, NY: Continuum. (Original work published 1960).

Gazzaniga, M. (1985). The social brain. New York, NY: Basic Books.

Gill, C. (1996). Personality in Greek epic, tragedy, and philosophy. Oxford, England: Clarendon.

Gill, C., \& McCabe, M. (1996). Form and argument in Late Plato. Oxford, England: Clarendon.

Gonzalez, F. (1998). Dialectic and dialogue. Evanston, Ill: Northwestern University Press.

Gonzalez, F. J. (2016). Plato's perspectivism. Plato Journal, 16, 31-48.

Jaynes, J. (1976). The origin of consciousness in the breakdown of the bicameral mind. Boston, MA: Houghton Mifflin.

Kahn, C. (1996). Plato and the socratic dialogue: The philosophical use of a literary form. Cambridge, England: Cambridge University Press.

Kahn, C. (2005). The philosophical importance of the dialogue form for Plato. Graduate Faculty Philosophy Journal, 26(1), 13-28.

Long, A. G. (2013). Conversation and self-sufficiency in Plato. Oxford, England: Oxford University Press.

Loraux, N. (1982). Donc Socrate est immortel. In J.-P. Pontalis (Ed.), Le temps de la réflexion (Vol. 3, pp. 19-46). Paris, France: Gallimard.

McCabe, M. M. (2006). Form and the platonic dialogues. In H. H. Benson (Ed.), A companion to Plato (pp. 39-54). Hoboken, NJ: Blackwell Publishing.

Onians, R. (1988). The origins of European thought about the body, the mind, the soul, the world, time, and fate. Cambridge, England: Cambridge University Press.

Panaccio, C. (1999). Le discours intérieur. De Platon à Guillaume d'Ockham. Paris, France: Éditions du Seuil.

Plato. (1900-1907). In J. Burnet (Ed.), Platonis opera (Vol. 5). Oxford, England: Clarendon.

Plato. (1997). In J. Cooper \& D. Hutchinson (Eds.), Complete works. Indianapolis, IN: Hackett Publishing Company.

Renaut, O. (2013). De la voix au discours chez Platon. In M. Gaudemar (Ed.), Les plis de la voix (pp. 37-44). Limoges, France: Lambert-Lucas.

Ryle, G., \& Kolenda, K. (1979). On thinking. Totowa, NJ: Rowman and Littlefield.

Vernant, J.-P. (1991). The individual within the city-state. In F. I. Zeitlin (Ed.), Mortals and immortals: Collected essays. Princeton, NJ: Princeton University Press.

Williams, B. (1993). Shame and necessity. Berkeley, CA: University of California Press.

Wittgenstein, L. (2001). Philosophical investigations (G. E. M. Anscombe, Trans.). London, England: Blackwell. (Original work published 1953).

Woolf, R. (2008). Socratic authority. In P. Remes \& J. Sihvola (Eds.), Ancient philosophy of the self (pp. 77-107). Dordrecht, The Netherlands: Springer. 